\title{
Berichtigung
}

zu meinem Aufsatz: „ढ̈ber Bau und Entwickelung von physiologisch vorkommenden atypischen Spermien“*

(Anat. Hefte, Bd. 18, Heft 3)

von

\section{Ivar Broman.}

Wie mir Prof. Essen-M öller eben mitgeteilt hat, ist seine, in meiner obengenannten Arbeit S. 541 citierte Äusserung insofern zu korrigieren, dass er zweieiige $/$ willinge (nicht eineiige) gesagt hatte. Was ich am Schluss derselben Seite geschrieben habe, verliert natürlich durch diesen, von mir gemachten Irrtum - - den ich herzlich bedauere - seine Berechtigung. 